\title{
The Urokinase Plasminogen Activator Receptor (UPAR) Is Preferentially Induced by Nerve Growth Factor in PC12 Pheochromocytoma Cells and Is Required for NGF-Driven Differentiation
}

\author{
Robin Farias-Eisner, ${ }^{1-3}$ Linda Vician, ${ }^{2-4}$ Abigail Silver, ${ }^{3}$ Srinivasa Reddy, ${ }^{5}$ Shafaat A. Rabbani, ${ }^{6}$ and \\ Harvey R. Herschman $2-4$ \\ Departments of ${ }^{1}$ Obstetrics and Gynecology, ${ }^{2}$ Biological Chemistry, ${ }^{4}$ Molecular and Medical Pharmacology, and \\ ${ }^{5}$ Medicine and ${ }^{3}$ Molecular Biology Institute, University of California, Los Angeles, Center for the Health Sciences, Los \\ Angeles, California, and 'Department of Medicine and Oncology, McGill University and Royal Victoria Hospital, Montreal, \\ Quebec, Canada
}

\begin{abstract}
Nerve growth factor (NGF)-driven differentiation of PC12 pheochromocytoma cells is a well studied model used both to identify molecular, biochemical, and physiological correlates of neurotrophin-driven neuronal differentiation and to determine the causal nature of specific events in this differentiation process. Although epidermal growth factor (EGF) elicits many of the same early biochemical and molecular changes in PC12 cells observed in response to NGF, EGF does not induce molecular or morphological differentiation of PC12 cells. The identification of genes whose expression is differentially regulated by NGF versus EGF in PC12 cells has, therefore, been considered a source of potential insight into the molecular specificity of neurotrophin-driven neuronal differentiation. A "second gen-
\end{abstract}

In the PC12 pheochromocytoma cell model system, nerve growth factor (NGF) acts as a neurogenic agent, inducing a differentiation program. In contrast, epidermal growth factor (EGF) acts as a mitogen (Greene and Tischler, 1976; Huff et al., 1981; Chao, 1992; Bonni and Greenberg, 1997). NGF and EGF both rapidly induce the transcription of primary response or immediate-early genes, genes whose transcription requires only the activation of preexisting signaling molecules and transcription factors (Herschman, 1991). We showed previously that representational difference analysis (RDA) (Lisitsyn et al., 1993) is an effective way to clone genes that are differentially induced by NGF versus EGF in PC12 cells (Vician et al., 1997).

One advantage of RDA is that it can be iterated; cDNAs for genes known to be preferentially expressed in a given cell population can be added to the "driver" cDNA population, and RDA can be repeated. The previously identified genes enriched in the "tester" cDNA population should be eliminated, and additional amplicons that are elevated in the tester versus driver population should be enriched in the reiterated RDA procedure. We have

Received Aug. 26, 1999; revised Oct. 13, 1999; accepted Oct. 18, 1999.

This work was supported by National Institutes of Health Grant NS-28660 (H.R.H.) and Medical Research Council Grant of Canada Grant MT-12609 (S.A.R.). We thank Raymond Basconcillo for technical help, members of the Herschman laboratory for helpful discussions, and Duncan MacLaren for help in preparation of the figures.

Correspondence should be addressed to Dr. Harvey Herschman, Molecular Biology Institute, 611 Charles E. Young Drive East, Los Angeles, CA 90095-1570. E-mail: hherschman@mednet.ucla.edu.

Copyright (C) 1999 Society for Neuroscience $0270-6474 / 99 / 200230-10 \$ 15.00 / 0$ eration" representational difference analysis procedure now identifies the urokinase plasminogen activator receptor (UPAR) as a gene that is much more extensively induced by NGF than by EGF in PC12 cells. Both an antisense oligonucleotide for the UPAR mRNA and an antibody directed against UPAR protein block NGF-induced morphological and biochemical differentiation of PC12 cells; NGF-induced UPAR expression is required for subsequent NGF-driven differentiation.

Key words: urokinase plasminogen activator receptor; nerve growth factor; neurotrophin; PC12 pheochromocytoma cells; neuronal differentiation; primary response genes; immediateearly genes

used a "second generation" RDA procedure to identify additional genes that are preferentially induced in NGF- versus EGF-treated PC12 cells. One of the genes identified in this iterated RDA analysis of NGF-driven neuronal differentiation is the urokinase plasminogen activator receptor (UPAR).

UPAR is a glycosyl-phosphatidylinositol (GPI)-linked membrane protein lacking transmembrane and cytosolic domains (Ploug et al., 1991; Wang et al., 1995). Until recently, UPAR was considered incapable of transducing extracellular signals across the plasma membrane; its function was thought to be limited to localization of plasminogen activation to the cell surface. This cell surface activity is known to facilitate cellular movement by proteolytic extracellular matrix degradation for tumor cell invasion, chemotaxis, and cellular adhesion (Ellis et al., 1991; Moller, 1993; Gyetko et al., 1994; Sitrin et al., 1996; Xing and Rabbani, 1996; Cantero et al., 1997). More recently UPAR-mediated activation of intracellular-signaling pathways, including diacylglycerol accumulation (Del Rosso et al., 1993; Anichini et al., 1997), modulation of cAMP levels (Goretzki and Mueller, 1997), release of calcium from internal stores (Cao et al., 1995), and alterations in inositol phosphate turnover (Vilhardt et al., 1999), have been reported. Engagement of the UPAR also activates expression of immediate-early genes (Konakova et al., 1998). Interactions of UPAR in cells with a variety of signal transduction molecules, including integrins (Wei et al., 1996, 1999), tyrosine kinases (Resnati et al., 1996), and serine/threonine kinases (Brodie et al., 1999; Corbit et al., 1999), have been described. 
UPAR mRNA expression was demonstrated in differentiating neurons from the dorsal root ganglion of mice (Hayden and Seeds, 1996), suggesting a possible role for UPAR in neuronal differentiation. In this study, we first show that UPAR mRNA and protein are differentially induced by NGF in PC12 cells. We then use an antisense oligonucleotide directed against the UPAR message and an antibody directed against the UPAR protein to demonstrate that induced UPAR expression is necessary for NGF-induced PC12 cell differentiation.

\section{MATERIALS AND METHODS}

Cell culture. PC12 cells were cultured as described in RPMI with $10 \%$ heat-inactivated horse serum and 5\% fetal calf serum (Vician et al., 1997). Before all experiments, the cells were rinsed with serum-free DMEM and shifted to serum-free DMEM with high glucose for $24 \mathrm{hr}$ before treatment. NGF and EGF were obtained from Collaborative Biomedical Products (Bedford, MA). Cycloheximide was obtained from Sigma (St. Louis, MO).

$R D A$. The RDA subtraction experiments were performed using RNA from low-density, serum-starved PC12 cells treated for 45 min or 1, 2, 3, or $4 \mathrm{hr}$ with either NGF or EGF. RNA was purified, pooled, and poly $\left(\mathrm{A}^{+}\right)$selected using PolyATtract (Promega, Madison, WI). Doubled-stranded cDNAs were synthesized as described previously (Vician et al., 1997). To maximize the possibility of cloning amplicons from cDNAs of lower abundance, the more highly abundant, previously cloned cDNAs were gel purified and added to $1000 \mathrm{ng}$ of driver cDNA (EGF cDNA): VGF (10 ng), ARC (10 ng), collagenase $(2.5 \mathrm{ng})$, plasminogen activator inhibitor (PAI; $2.5 \mathrm{ng}$ ), and transin (1.0 ng). The tester cDNA (NGF cDNA) was unmodified. Tester and driver cDNAs were digested with Sau3a. The restriction fragments were ligated to the $\mathrm{L} \mathrm{Bgl}$ adapters (Vician et al., 1997) and amplified by PCR to prepare the starting amplicons. Five rounds of RDA followed (Vician et al., 1997). The beginning driver/tester ratio (H1) was 100:1. The second (H2), third $(\mathrm{H} 3)$, fourth $(\mathrm{H} 4)$, and fifth $(\mathrm{H} 5)$ round driver/tester ratios were 1000 , $5 \times 10^{4}, 5 \times 10^{5}$, and $5 \times 10^{6}$, respectively. After the fifth round of RDA selection the amplicon products were digested with Sau3a and cloned into the pCR II cloning vector (Invitrogen, Carlsbad, CA). Plasmid DNA from 160 individual colonies was digested with EcoRI and analyzed by gel electrophoresis. Five clones with inserts of different sizes were selected. These inserts were gel purified (Qiagen, Valencia, CA). Ten nanograms of each purified insert were pooled and $\left[\alpha^{-}{ }^{32} \mathrm{P}\right] \mathrm{dCTP}$ labeled using the $\mathrm{L} \mathrm{Bgl} 20 \mathrm{mer}$ as a specific primer. cDNAs from the VGF, transin, collagenase, PAI-1, and MKP-3, genes previously cloned using RDA (Vician et al., 1997), were also pooled and $\left[\alpha^{-}{ }^{32} \mathrm{P}\right] \mathrm{dCTP}$ labeled using a random-priming reaction. Two separate dot blots, containing all 160 cloned amplicon inserts, were hybridized with either the labeled amplicon inserts or the pooled, previously cloned genes. Clones that hybridized to either mixed probe were eliminated from further study. This process was repeated until the original group of clones was reduced from 160 to 40 . The 40 remaining clones were subjected to EcoRI digestion, and the products were separated on duplicate $1.5 \%$ NuSieve gels. Radioactive probes, synthesized from the NGF- and EGF-induced starting populations of mRNA using both $\left[\alpha-{ }^{32} \mathrm{P}\right] \mathrm{dCTP}$ and $\left[\alpha-{ }^{32} \mathrm{P}\right] \mathrm{dATP}$, were hybridized to the two membranes. After $3 \mathrm{~d}$ of hybridization at $42^{\circ} \mathrm{C}$, the filters were washed twice at room temperature and five times at $65^{\circ} \mathrm{C}$ in $2 \times \mathrm{SSPE}$ and $0.5 \%$ SDS. Filters were exposed sequentially to both Kodak X-Omat AR film and Kodak Biomax MS ultrasensitive film to obtain adequate signal. The duplicate Southern blots were then compared for differential signals. Twelve of the 40 unknown clones that gave differential signals were sequenced. The DNA sequences obtained were compared with the current version of the nonredundant, updated GenBank+EMBL database using BlastN (Altschul et al., 1990). An amplicon from the UPAR gene was identified in this manner.

Northern blot analysis. After treatment, PC12 cells were washed once in PBS and harvested in RLT lysis buffer (Qiagen). Total RNA was purified using RNeasy (Qiagen). Northern blot analysis was performed as described previously (Vician et al., 1997). The blots were cross-linked using a Stratagene UV cross-linker and hybridized to $\left[\alpha-{ }^{32} \mathrm{P}\right] \mathrm{dCTP}-$ labeled cDNA probes. Quantitation was performed by phosphorimager analysis. The $1.2 \mathrm{~kb}$ UPAR rat cDNA was described previously (Rabbani et al., 1994).
Western blot analysis. After treatment, $\mathrm{PC} 12$ cells were washed three times in PBS and harvested in SDS-loading buffer $(50 \mathrm{~mm}$ Tris- $\mathrm{HCl}, \mathrm{pH}$ 6.8, $100 \mathrm{~mm}$ dithiothreitol, $2 \%$ SDS, $0.1 \%$ bromphenol blue, and $10 \%$ glycerol). Samples were boiled for $10 \mathrm{~min}$, and protein concentrations were determined by the Bradford assay. Fifty micrograms of the protein extract were subjected to SDS-PAGE (5\% stacking gel and $8 \%$ resolving gel), using a Tris-glycine buffer, $\mathrm{pH} 8.3$. The proteins were blotted onto nitrocellulose membranes at $4^{\circ} \mathrm{C}$ overnight, using a Bio-Rad (Hercules, CA) transfer apparatus. The filters were incubated for $1 \mathrm{hr}$ in PBS containing $0.2 \%$ Tween 20 and $10 \%$ nonfat milk, washed in $0.2 \%$ Tween 20 and $1 \%$ nonfat milk, and incubated with either the rabbit anti-rat UPAR IgG directed against the N-terminal end (domains 1 and 2) of rat UPAR (Degryse et al., 1999) at a dilution of 1:1000, the mouse anti-rat cyclooxygenase-1 (COX-1) IgG (Cayman Chemical, Ann Arbor, $\mathrm{MI}$ ) at a dilution of 1:6000, the rabbit anti-rat $\mathrm{Na}^{+}$channel $\operatorname{IgG}$ (Upstate Biotechnology, Lake Placid, NY) at a dilution of 1:2000, or the mouse anti-rat glyceraldehyde-3-phosphate dehydrogenase (GAPDH) IgG (Chemicon, Temecula, CA) at a dilution of 1:6000 for $1 \mathrm{hr}$. After three additional washes in PBS containing $0.2 \%$ Tween 20 and $1 \%$ nonfat milk for $1 \mathrm{hr}$, the filters were incubated with a secondary antibody (anti-rabbit IgG conjugated to horseradish peroxidase; Sigma) at a dilution of 1:8000. Immunodetection was performed with the ECL reagents (Pharmacia, Piscataway, NJ). The filters were exposed to Kodak XAR-5 film. The specificity of the UPAR antipeptide antiserum has been demonstrated previously (Rabbani, 1998; Degryse et al., 1999).

Immunofluorescence analysis. PC12 cells were plated on collagencoated two-chamber slides (Fisher Scientific, Pittsburgh, PA) and treated as indicated in the legends to the figures. The wells of each slide required a volume of $0.5 \mathrm{ml}$ of growth medium. Cells were prepared for transient transfection as described in Antisense Assay. Cultures were washed twice in PBS and fixed in $2 \%$ paraformaldehyde prepared in PBS. The fixed cultures were rinsed in PBS and were further washed in PBS with glycine and Triton X-100 ( $0.1 \mathrm{M}$ glycine and $0.05 \%$ Triton X-100 prepared in PBS) for $20 \mathrm{~min}$ at room temperature. The cultures were first incubated in normal goat serum (1:20 dilution) for $30 \mathrm{~min}$ and then overnight at $4{ }^{\circ} \mathrm{C}$ with the anti-UPAR antibody at a dilution of 1:100 in PBS with $0.2 \%$ Tween 20 (PBS-T). After three 10 min washes with PBS-T, the cultures were incubated for $1 \mathrm{hr}$ with anti-rabbit fluorescein isothiocyanate-conjugated $\operatorname{IgG}$ (Sigma) at 1:50 dilution. The cultures were washed three times for $20 \mathrm{~min}$ each, dried, mounted in buffered glycerol containing $1 \mathrm{mg} / \mathrm{ml}$ paraphenylenediamine, and analyzed with a Zeiss photomicroscope III. Exposures were for $8 \mathrm{sec}$ at a $100 \times$ magnification in all cases, using Kodak Tri-X pan 400 film (see Figs. 2, 3).

Antisense assay. The three-component, 19 nucleotide chimeric antisense oligonucleotide, purchased from Oligos Etc. (Wilsonville, OR), contains a $5^{\prime}$ exonuclease-resistant RNase $\mathrm{H}$-activating region of $6 \mathrm{nu}-$ cleotides (phosphorothioate antisense DNA) linked to a region of 13 nucleotides ( $2^{\prime} O$-methyl-substituted antisense RNA) and a $3^{\prime}$-terminal $3^{\prime}-3^{\prime}$-linked "inverted" nucleotide $(\mathrm{T})$ as described by the manufacturer. This chimera is stable against endonucleases. The antisense oligonucleotide sequence used was 5' -TCTTCGTAGGAACATCCAA-3', based on nucleotides 693-712 of the rat UPAR-coding sequence (Rabbani et al., 1994). The corresponding sense oligonucleotide sequence used was 5'TTGGATGTTCCTACGAAGA-3'. Both antisense and sense oligonucleotides were HPLC purified. Antisense or sense oligonucleotides were diluted with serum-free DMEM. SuperFect reagent (Qiagen) was added to each oligonucleotide solution $(2 \mu \mathrm{l}$ of SuperFect reagent per $\mu \mathrm{g}$ of oligonucleotide) to a final volume of $200 \mu \mathrm{l}$, vortexed for $10 \mathrm{sec}$, and incubated at room temperature for $15 \mathrm{~min}$ to allow the SuperFect reagent-DNA complex formation. The transfection complexes were added to the $100 \mathrm{~mm}$ plates to yield a $3 \mu \mathrm{M}$ final oligonucleotide concentration and incubated for $1 \mathrm{hr}$ before the addition of NGF (5O $\mathrm{ng} / \mathrm{ml}$ ). Protein for Western blot analysis and total RNA for Northern blot analysis were prepared as described above.

Neutralizing-antibody assay. The rat UPAR antipeptide antiserum and the control antiserum were diluted with serum-free DMEM and added to the $100 \mathrm{~mm}$ plates to yield a $50 \mu \mathrm{g} / \mathrm{ml}$ final concentration, and the cells were further incubated for $1 \mathrm{hr}$ before the addition of NGF $(5 \mathrm{O} \mathrm{ng} / \mathrm{ml})$. The cells were photographed $24 \mathrm{hr}$ after addition of NGF. Protein for Western blot analysis and total RNA for Northern blot analysis were collected as described above.

Phase-contrast microscopy. For both antisense and antibody inhibition studies, cells were photographed with a Leica phase-contrast microscope, using Kodak TMAX 400 black-and-white film. 


\section{RESULTS}

Representational difference analysis identifies a UPAR amplicon preferentially induced by NGF versus EGF in PC12 cells

We showed previously that RDA is an effective way to clone genes that are differentially induced by NGF versus EGF in PC12 cells (Vician et al., 1997). To improve the efficiency of a second generation RDA search for NGF-induced genes, the driver cDNA population (from EGF-treated cells) was "doped" with cDNAs for the genes we identified previously (ARC, collagenase-1, and plasminogen activator inhibitor-1) and for VGF and transin. When the RDA protocol was subsequently performed, the doped amplicons were eliminated from the tester populations in the early rounds. Southern blot analysis showed that by round 5 all of these species were eliminated (data not shown), along with GAPDH and tyrosine hydroxylase. Previously uncloned tester amplicons, present in low abundance, were able to compete successfully and emerged enriched in the later RDA rounds.

After the fifth RDA round, NGF-enriched amplicons were cloned as described in Materials and Methods, and individual amplicon inserts were sequenced. Sequences were compared with the current version of the nonredundant, updated GenBank+ EMBL database using BlastN (Altschul et al., 1990). An amplicon from the UPAR gene was identified in this manner.

\section{UPAR mRNA and protein are preferentially induced by NGF versus EGF in PC12 cells}

To confirm that UPAR is preferentially induced by NGF in PC12 cells and to determine the magnitude and duration of UPAR induction, we analyzed UPAR mRNA accumulation in response to NGF and EGF treatment (Fig. $1 A$ ). NGF is a much more effective inducer of UPAR expression than is EGF. To be certain that EGF effectively stimulated PC12 cells in this experiment, the filter was stripped and reprobed for TIS8/EGR1 mRNA. EGR1 is a primary response gene induced by both NGF and EGF (Arenander et al., 1989; DeFranco et al., 1993; Kujubu et al., 1993; Vician et al., 1997). EGR1 mRNA is effectively induced by EGF. We also examined this set of RNAs for VGF expression. VGF is a primary response gene that is also differentially induced by NGF versus EGF. VGF encodes a protein targeted for secretory vesicles (Possenti et al., 1989). Finally, the blots were stripped and probed with GAPDH to normalize mRNA levels. Quantitation of mRNAs was performed by phosphorimager analysis (Fig. 1B). UPAR mRNA is induced much more by NGF than by EGF. NGF-induced UPAR mRNA levels reach a peak at $2 \mathrm{hr}$ ( $\sim 9$ times the EGF level and nearly 13 times the control level) and remain modestly induced for the $8 \mathrm{hr}$ duration of the experiment. These levels of induction have been observed in a large number of experiments. EGR1 and VGF mRNA levels peak at 0.5 and $4 \mathrm{hr}$, respectively. UPAR mRNA is also induced by NGF in the presence of cycloheximide in PC12 cells (data not shown); UPAR is a "primary response gene" or "immediate-early gene" whose induction depends only on preexisting signaling components and transcriptional regulators and requires no intervening protein synthesis (Herschman, 1991).

UPAR protein is also induced by NGF in PC12 cells (Fig. 2). After NGF stimulation, induction of UPAR protein reaches a peak at $4 \mathrm{hr}$ and remains modestly elevated for the $24 \mathrm{hr}$ duration
A.
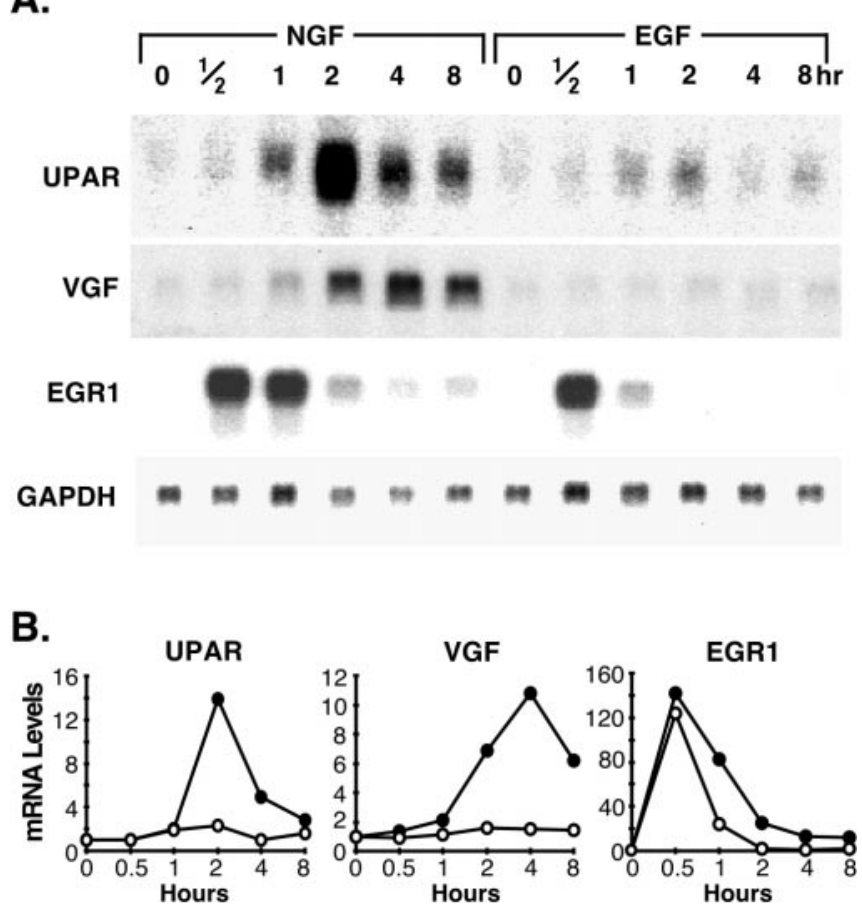

Figure 1. NGF preferentially induces UPAR mRNA in PC12 cells. $A$, Northern blot analysis of UPAR, VGF, EGR1, and GAPDH mRNA in PC12 cells treated with NGF $(50 \mathrm{ng} / \mathrm{ml})$ or EGF $(25 \mathrm{ng} / \mathrm{ml})$ for the times, in hours, indicated. Each lane contains $8 \mu \mathrm{g}$ of total RNA. B, Quantitation, by phosphorimager analysis, of the induction of UPAR, VGF, and EGR1 mRNAs by NGF (closed circles) or EGF (open circles). Data are normalized to the levels of GAPDH mRNA.

of the experiment (Fig. 2A). UPAR protein expression in response to NGF and EGF was also examined by immunofluorescence (Fig. 2B). These data confirm the striking preferential induction of UPAR by NGF relative to EGF.

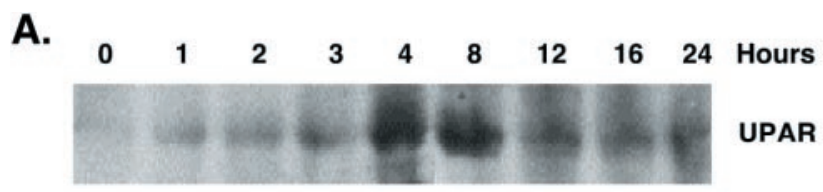

B.

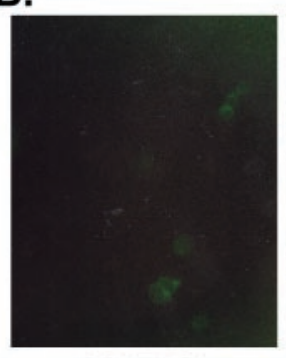

CONTROL

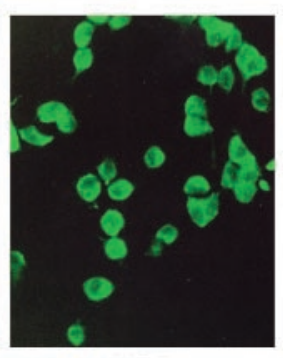

NGF

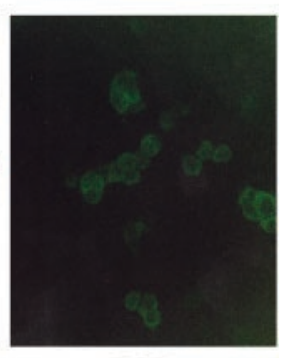

EGF
Figure 2. NGF preferentially induces UPAR protein in PC12 cells. $A$, Time course for UPAR protein induction, by Western blot analysis, by NGF in PC12 cells. Each lane contains $50 \mu \mathrm{g}$ of protein. $B$, Immunofluorescence analysis of UPAR protein in control PC12 cells, cells treated with NGF $(50 \mathrm{ng} / \mathrm{ml})$, and cells treated with EGF $(25 \mathrm{ng} / \mathrm{ml})$ for $4 \mathrm{hr}$. Magnification, $100 \times$. 
A.

B.
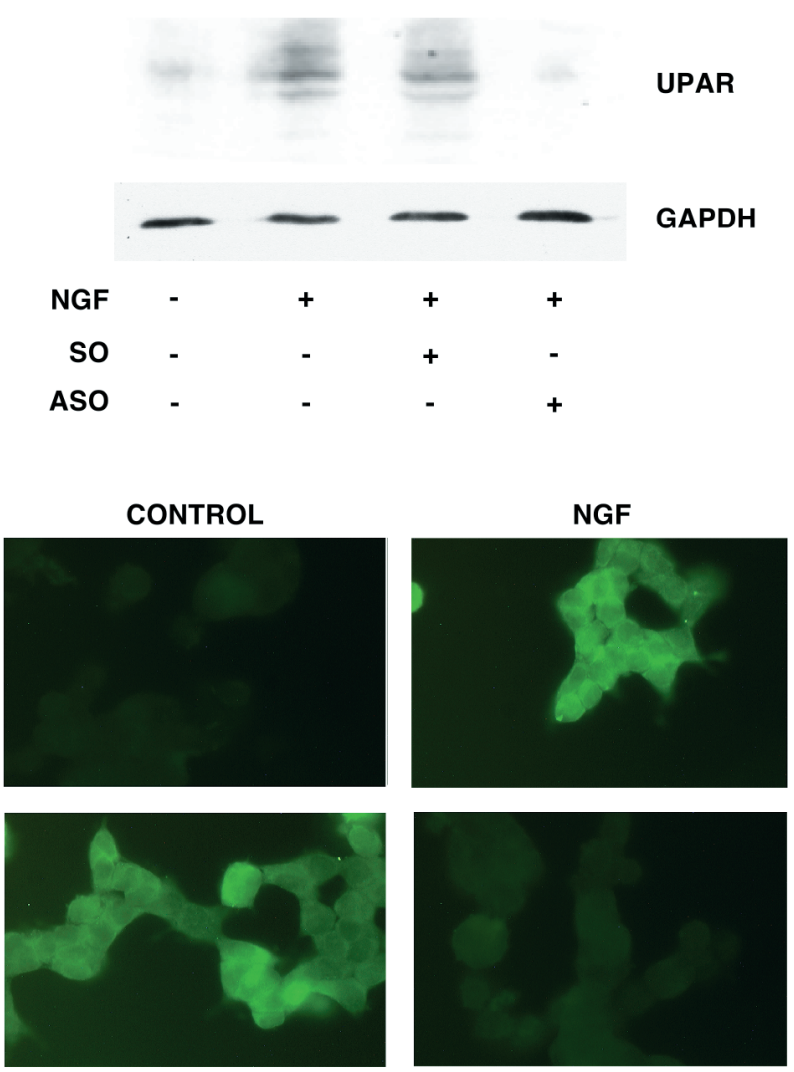

NGF + SENSE OLIGO

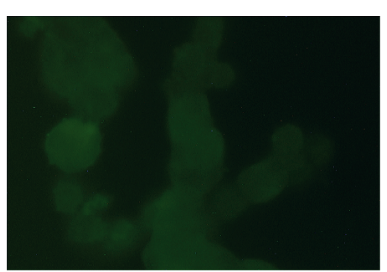

$\mathrm{NGF}+\mathrm{AS}$ OLIGO

Figure 3. Antisense oligonucleotide for UPAR blocks NGF-induced UPAR protein accumulation in PC12 cells. $A$, PC12 cells were exposed to NGF $(50 \mathrm{ng} / \mathrm{ml})$ in the presence of UPAR SO or ASO $(3 \mu \mathrm{M})$ for $4 \mathrm{hr}$. Cell extracts were prepared and used for Western blot analysis with antibodies to UPAR and GAPDH. Each lane contains $50 \mu \mathrm{g}$ of protein. $B$, Cells were treated as described in $A$. Four hours after the initiation of treatment the cells were fixed and used for immunofluorescence analysis of UPAR protein. Magnification, 200×. AS, Antisense; OLIGO, oligonucleotide.

\section{UPAR antisense oligonucleotide blocks NGF-directed morphological differentiation of PC12 cells}

An antisense phosphorothioate oligonucleotide for UPAR is able to block human monocyte chemotaxis (Gyetko et al., 1994) and adhesion (Sitrin et al., 1996). We used an oligonucleotide with the corresponding antisense sequence for rat UPAR [nucleotides 693-712 of the rat UPAR-coding region (Rabbani et al., 1994), corresponding to nucleotides 720-738 of the human UPAR mRNA (Roldan et al., 1990; Gyetko et al., 1994)] to investigate the role of NGF-induced UPAR expression in PC12 cell differentiation. We first established the ability of the rat UPAR antisense oligonucleotide to block UPAR protein accumulation in response to NGF in PC12 cells. A nucleotide DNA/RNA chimera antisense oligonucleotide (ASO) that minimizes toxicity to PC12 cells was used (Agrawal and Zhao, 1998a,b). The corresponding sense oligonucleotide (SO) was used as the control.

Low-density, serum-starved PC12 cells were transfected with UPAR ASO or the corresponding SO and then treated with NGF. Extracts were prepared and analyzed by Western blot for UPAR and GAPDH protein levels (Fig. $3 A$ ). The UPAR ASO effectively blocks NGF-induced UPAR accumulation. In contrast, the UPAR SO does not effect UPAR induction. Immunofluorescence analysis confirmed the ability of the UPAR antisense

CONTROL

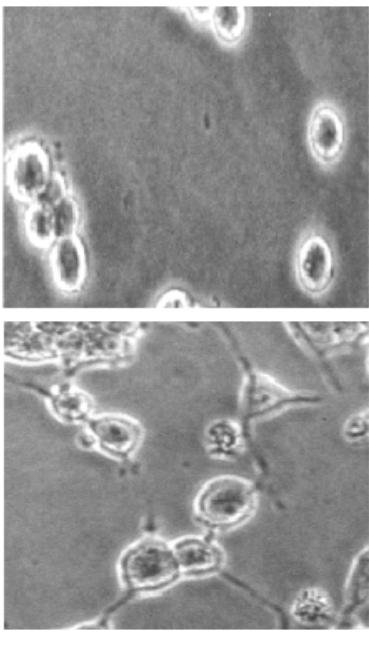

NGF + SENSE OLIGO
NGF

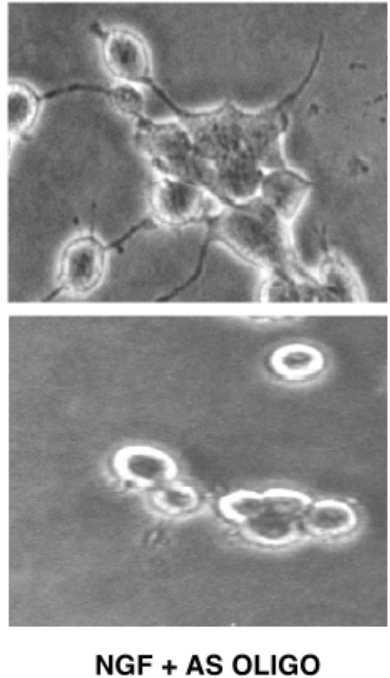

Figure 4. Antisense oligonucleotide for UPAR blocks NGF-driven PC12 cell morphological differentiation. Cells were treated with NGF and UPAR sense and antisense oligonucleotides as described in the legend to Figure 3. Twenty-four hours later the cells were photographed. Magnification, $200 \times$

oligonucleotide to block NGF-induced expression of UPAR protein (Fig. 3B).

To examine whether induced UPAR expression is required for NGF-driven differentiation of PC12 cells, we analyzed the ability of UPAR ASO to block the NGF-driven morphological response. UPAR ASO blocks NGF-directed morphological differentiation of PC12 cells (Fig. 4). In contrast, treatment with UPAR SO has no effect on NGF-directed morphological differentiation.

\section{UPAR ASO blocks expression of genes associated with NGF-driven PC12 cell differentiation}

The induced expression of the sodium channel (Toledo-Aral et al., 1995; Hilborn et al., 1997) and COX-1 (Kaplan et al., 1997) accompanies the NGF-induced morphological differentiation of PC12 cells. These proteins, therefore, serve as molecular markers of NGF-driven neuronal differentiation. To examine whether UPAR ASO blocks these measures of NGF-driven neuronal differentiation, extracts of NGF-treated PC12 cells incubated in the presence of UPAR ASO and UPAR SO were assayed for COX-1 (Fig. 5A) and type II sodium channel (Fig. $5 B$ ) expression. UPAR ASO blocks expression of both type II sodium channel protein and COX-1. UPAR SO does not modify sodium channel or COX-1 induction.

\section{UPAR ASO blocks NGF induction of secondary response genes but not primary response or immediate-early genes in PC12 cells}

NGF treatment of PC12 cells induces expression of a constellation of primary response genes (Herschman, 1991), which we now know to include UPAR, as a result of the activation of preexisting transcription factors. We first examined whether UPAR ASO blocks induction of immediate-early genes (IEGs) other than UPAR. PC12 cells were treated with NGF and either UPAR ASO or UPAR SO. Cells were harvested $2 \mathrm{hr}$ after treatment, and extracts were analyzed for UPAR, VGF, and EGR1 mRNA levels (Fig. 6). As expected, UPAR ASO blocks NGF-induced UPAR mRNA accumulation. However, UPAR ASO has no effect 
A.

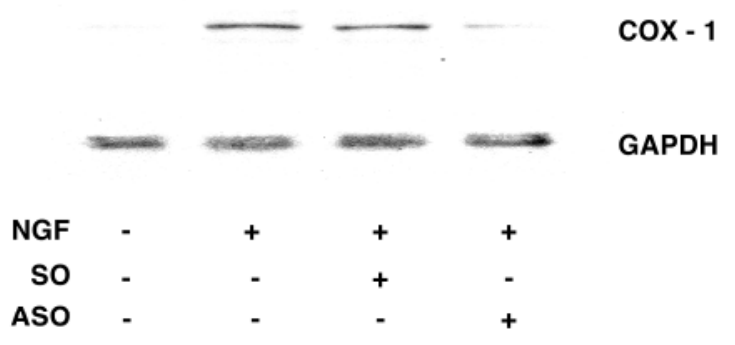

B.

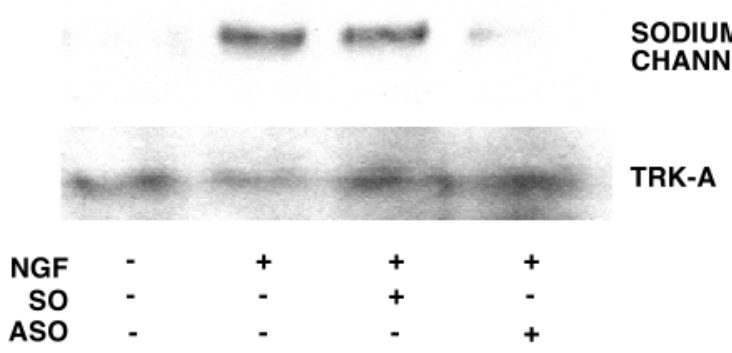

Figure 5. Antisense oligonucleotide for UPAR blocks induction of genes associated with NGF-driven PC12 cell differentiation. PC12 cells were treated with NGF and sense and antisense oligonucleotides as described in the legend to Figure 3. After $24 \mathrm{hr}$, cells were harvested, and extracts were prepared for Western blot analysis. Each lane contains $50 \mu \mathrm{g}$ of protein. $A$, Western blot analysis of COX-1 protein. The blot was also probed with an antibody to GAPDH for normalization. $B$, Western blot analysis of the type II sodium channel protein. The blot was also probed with an antibody to TrkA for normalization.

on expression of the other IEGs; these aspects of NGF-induced signaling in PC12 cells are unaffected by blocking UPAR expression.

NGF also induces expression of "secondary response genes," genes whose transcription requires the previous synthesis of IEG proteins. We next examined whether UPAR ASO blocks NGF induction of secondary response genes. The secondary response genes known to be induced most rapidly by NGF in PC12 cells are two metalloproteinases, collagenase-1 (Vician et al., 1997) and transin (also known as stromelysin-1) (Machida et al., 1989). The mRNAs for collagenase-1 and transin can be detected in PC12 cells as early as $2 \mathrm{hr}$ after NGF treatment (de Souza et al., 1995; Vician at al., 1997). The Northern blots of Figure 6 were stripped and reprobed to measure the levels of collagenase- 1 and transin. UPAR ASO completely prevents NGF induction of both collagenase-1 and transin. NGF-induced UPAR expression, therefore, appears to be required for NGF-driven secondary response gene expression in PC12 cells. As before, the UPAR SO has no effect on NGF-driven gene expression.

\section{UPAR ASO does not prevent induction of gene expression in PC12 cells by NGF-independent signaling pathways}

Blockade of UPAR expression might generally interfere with gene expression in PC12 cells, especially at the later times associated with NGF-induced morphological differentiation. We next asked whether blocking UPAR expression prevents all signal transduction in PC12 cells or is restricted to "downstream" signaling in response to NGF.

Another goal of our laboratory has been to identify genes induced in neurons by depolarization or forskolin but not by

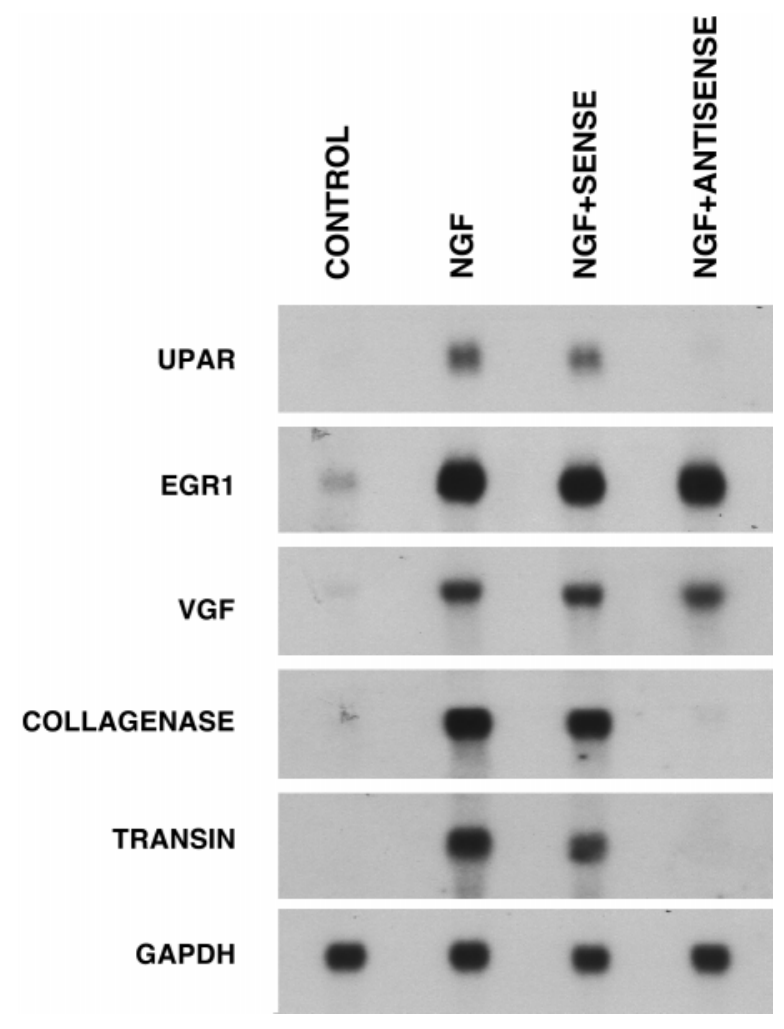

Figure 6. Antisense oligonucleotide for UPAR has no effect on NGFinduced expression of primary response or immediate-early genes in PC12 cells but blocks induction of NGF-induced secondary response genes. PC12 cells were treated with NGF and sense and antisense oligonucleotides as described in the legend to Figure 3. Cells were harvested at $2 \mathrm{hr}$, and RNA was prepared for Northern blot analysis. Blots were hybridized to labeled probes for the primary response or immediate-early genes UPAR, EGR1, and VGF, for the secondary response genes collagenase-1 and transin, and for GAPDH. Each lane contains $8 \mu \mathrm{g}$ of RNA.

neurotrophins or growth factors (Vician et al., 1997; Feldman et al., 1998a,b). Kinase induced by depolarization 1 (KID-1) encodes a protein kinase whose expression is induced in PC12 cells by depolarization or by forskolin but cannot be induced by NGF or EGF (Feldman et al., 1998a). We used forskolin induction of KID-1 to examine the effect of UPAR ASO on NGFindependent signal transduction pathways. PC12 cells were treated with NGF and either UPAR ASO or UPAR SO for 2 or $22 \mathrm{hr}$. The cells were then treated with forskolin. Two hours later, cells were harvested, and extracts were prepared. Northern blots were first probed for KID-1 and then stripped and reprobed for collagenase-1. The blot was stripped once again and probed for GAPDH. As expected, UPAR ASO blocks collagenase-1 expression $4 \mathrm{hr}$ after addition of NGF (Fig. 7). Morphological differentiation at $24 \mathrm{hr}$ is also blocked (data not shown). In contrast, neither 4 nor $24 \mathrm{hr}$ of exposure to UPAR ASO has any effect on the induction of KID-1 by forskolin. Despite their inability to express either NGF-induced secondary response genes or a morphological response to NGF in the presence of UPAR ASO, PC12 cells treated with UPAR ASO are able to mount a normal transcriptional response to forskolin stimulation.

\section{Anti-UPAR antibody prevents NGF-driven differentiation of PC12 cells}

Blockade of UPAR expression by UPAR ASO prevents NGFdriven PC12 cell differentiation. UPAR is a cell surface protein. 


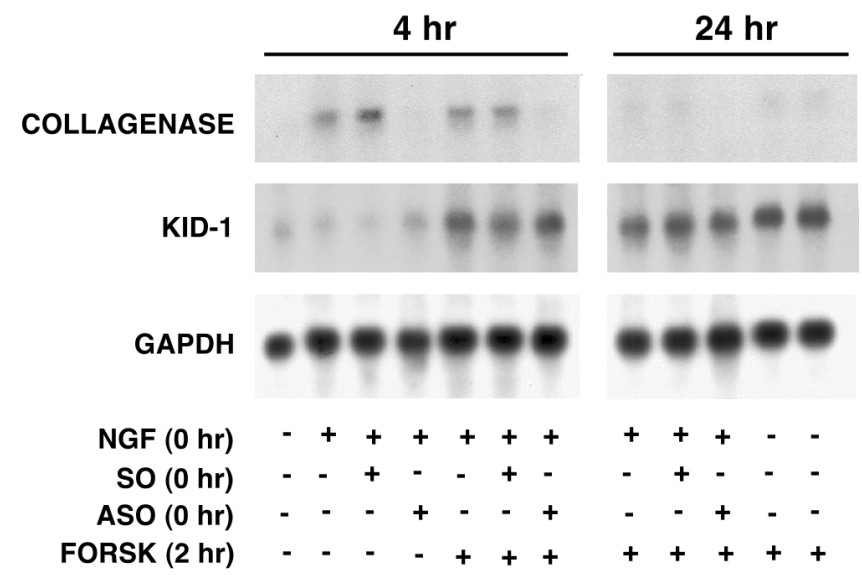

Figure 7. Antisense oligonucleotide for UPAR does not block forskolin induction of the KID-1 gene in PC12 cells. PC12 cells were treated with NGF and sense and antisense oligonucleotides as described in the legend to Figure 3. Left, At $2 \mathrm{hr}$ after NGF treatment, forskolin was added to the indicated populations of cells. Two hours later, at $4 \mathrm{hr}$ after the initial addition of NGF and oligonucleotides, the cells for the experiment were harvested, and RNA was prepared for Northern blot analysis. Right, For these cells, forskolin was added $22 \mathrm{hr}$ after the cells were treated with NGF and oligonucleotides. Two hours later, the cells were harvested, and RNA was prepared for Northern analysis. Left, Right, The blots were first hybridized to a KID-1 probe. After autoradiography, the blot was stripped, rehybridized to a labeled probe for collagenase, and again subjected to autoradiography. The blot was stripped a third time, rehybridized to a labeled probe for GAPDH, and subjected to autoradiography for a third time. FORSK, Forskolin.

We next examined whether an antibody that interacts with UPAR at the cell surface can also prevent NGF-driven PC12 cell differentiation. These experiments provide a second method, independent of antisense effects, to evaluate the requirement for induced UPAR gene expression in NGF-driven PC12 cell differentiation.

We first assessed whether anti-UPAR antibody can prevent NGF-driven PC12 cell morphological differentiation. Cells were treated with NGF and either a preimmune serum or antibody to UPAR. Anti-UPAR antibody blocks NGF-induced morphological differentiation (Fig. 8A). Anti-UPAR antibody treatment also blocks NGF induction of both COX-1 (Fig. $8 B$ ) and sodium channel (Fig. $8 C$ ) expression, two biochemical measures of NGFinduced PC12 cell differentiation.

Antisense inhibition experiments suggest that NGF-induced UPAR expression is required very early in the NGF-driven differentiation response. Induction of collagenase- 1 and transin, whose messages appear in NGF-treated PC12 cells within 2-4 hr, is blocked by UPAR ASO treatment. We also tested whether antibody to UPAR can interfere with the UPAR-mediated functions required at this early stage of NGF-induced differentiation. PC12 cells were treated with NGF, along with either a control serum or UPAR antiserum. Extracts prepared $2 \mathrm{hr}$ later were analyzed for collagenase-1 mRNA (Fig. 9). Treatment with antiUPAR antiserum prevents NGF-induced collagenase- 1 expression (Fig. 9).

Antibody to UPAR might have a generalized inhibitory effect on gene expression in PC12 cells, especially at later times after exposure of cells to this reagent. To determine whether exposure to anti-UPAR antibody has a general effect on gene expression in PC12 cells, we investigated the ability of cells treated with this antibody to express KID-1 in response to forskolin (Feldman et al., 1998a). PC12 cells were treated for either 2 or 22 hr with NGF
A.
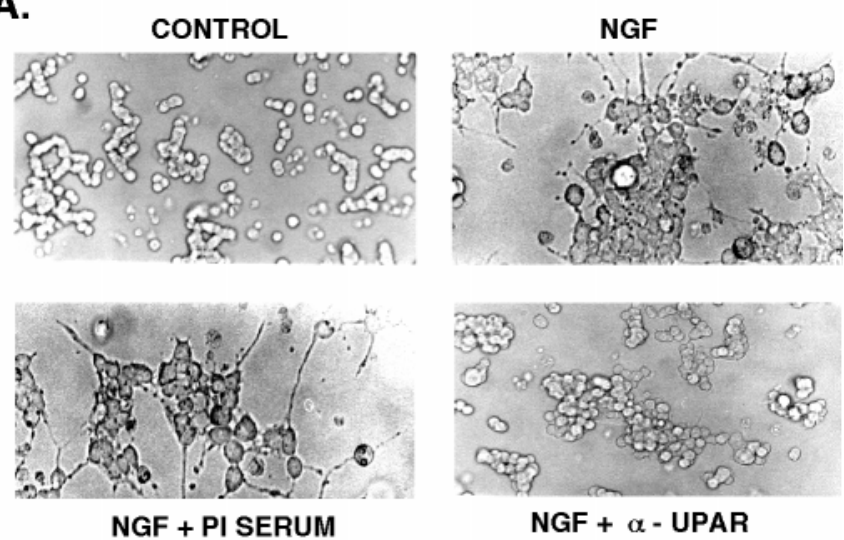

B.

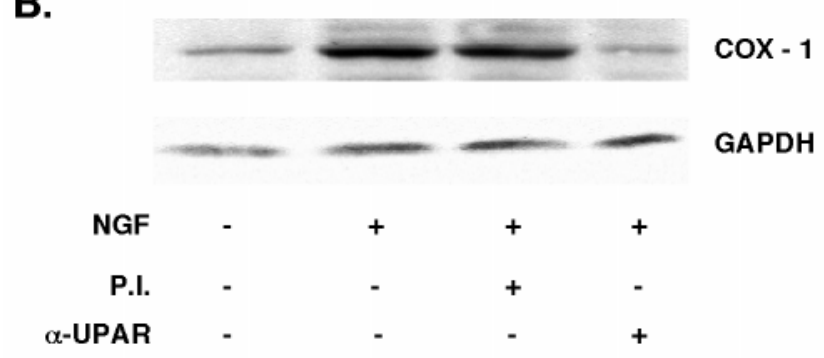

C.
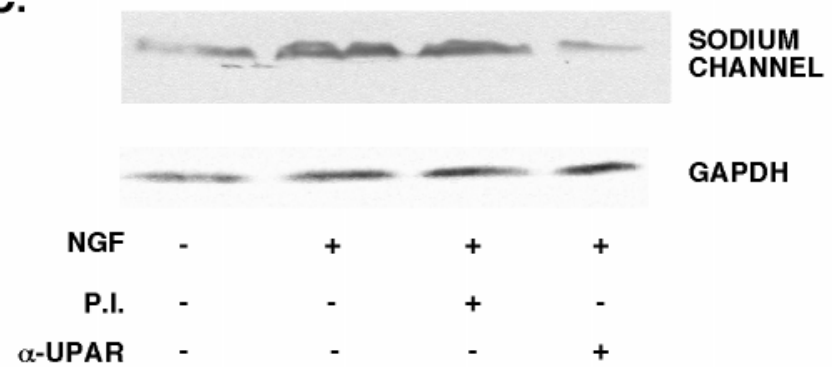

Figure 8. Anti-UPAR antibody blocks morphological and biochemical differentiation of PC12 cells in response to NGF. PC12 cells were treated with NGF alone or with NGF and either preimmune serum or antibody to UPAR. Antisera were added $30 \mathrm{~min}$ before NGF. A, Cells were photographed $24 \mathrm{hr}$ after NGF addition. Magnification, $100 \times . B$, C, Cells were harvested, and extracts were prepared for Western blot analysis. Each lane contains $50 \mu \mathrm{g}$ of protein. $B$, Western blot of COX-1 protein is shown. $C$, Western blot of the type II sodium channel protein is shown. The blots were also probed with antibody to GAPDH for normalization. $\forall-U P A R$, Antibody to UPAR; PI or P.I., preimmune.

and either control or anti-UPAR antisera (Fig. 9). The cells were then treated with forskolin. Two hours later, cells were harvested, extracts were prepared, and RNA was analyzed for KID-1 expression. Either a 4 or $24 \mathrm{hr}$ exposure to anti-UPAR antibody has no effect on the ability of forskolin to induce KID-1 in PC12 cells; the cells are relatively unaffected by UPAR antibody, except in their capacity to differentiate in response to NGF.

\section{DISCUSSION}

UPAR is preferentially induced by NGF in PC12 cells and is required for NGF-driven differentiation

Our goals are (1) to identify genes that are differentially induced by neurotrophins and (2) to determine which of these genes are required for neurotrophin-driven differentiation. We used previously RDA to identify genes that are differentially induced in 


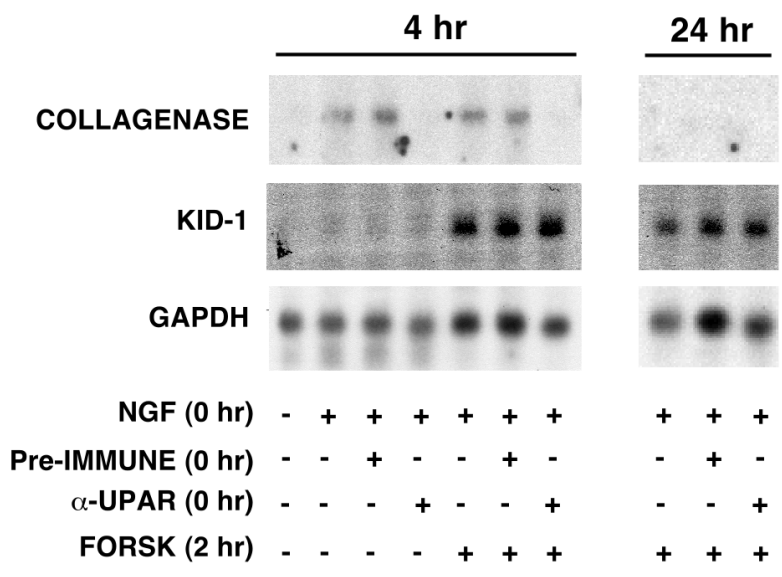

Figure 9. Anti-UPAR antibody blocks induction of NGF-induced secondary response genes but does not block forskolin induction of the KID-1 gene in PC12 cells. PC12 cells were treated with NGF, preimmune serum, and antibody to UPAR as shown in the figure. Left, At $2 \mathrm{hr}$ after NGF treatment, forskolin was added to the indicated populations of cells. Two hours later, at $4 \mathrm{hr}$ after the initial addition of NGF and antisera, the cells for the experiment were harvested, and RNA was prepared for Northern blot analysis. Right, For these cells, forskolin was added $22 \mathrm{hr}$ after the cells were treated with NGF and antisera. Two hours later, the cells were harvested, and RNA was prepared for Northern blot analysis. Left, Right, The blots were first hybridized to a KID-1 probe. After autoradiography, the blot was stripped, rehybridized to a labeled probe for collagenase, and again subjected to autoradiography. The blot was stripped a third time, rehybridized to a labeled probe for GAPDH, and subjected to autoradiography for a third time.

NGF- versus EGF-treated PC12 cells (Vician et al., 1997). Using a second-generation modification of RDA, we now report that UPAR is strikingly preferentially induced by NGF in PC12 cells.

UPAR joins a number of other genes, e.g., microtubuleassociated protein regulatory kinase 1 (Brown et al., 1999) and nitric oxide synthase (Peunova and Enikolopov, 1995; Poluha et al., 1997), that are induced by NGF and are thought to be required for NGF-driven morphological differentiation. However, the differential expression of these genes by NGF has not been explored, and early biochemical and molecular markers of NGFdriven differentiation have not been analyzed.

The earliest secondary gene transcriptional responses that distinguish NGF-driven neuronal differentiation from responses to other ligands in PC12 cells are the induction of transin (Machida et al., 1989) and collagenase (Vician et al., 1997). Transcription of transin and collagenase is observed in PC12 cells as early as $2 \mathrm{hr}$ after NGF exposure (de Souza et al., 1995; Vician et al., 1997) and is not induced by EGF. Blocking NGF-induced UPAR expression eliminates both transin and collagenase gene expression; NGF-driven UPAR expression and insertion into the membrane are required for continued progression of the NGF-induced differentiation response, even at this very early time.

Both UPAR antisense oligonucleotides and antibody treatment have no effect on the expression of primary response genes other than UPAR, suggesting that the signal transduction pathway(s) from the NGF receptor to activation of transcription factors necessary for NGF-induced immediate-early gene expression is intact. In addition, cells treated with either UPAR antisense oligonucleotides or UPAR antibody are fully competent to mount a primary gene induction response to a distinct stimulus; these cells are not compromised in their ability to respond to other environmental signals.
NGF-induced UPAR expression is transient, peaking within 4 hr after NGF addition and returning to near baseline levels within $8 \mathrm{hr}$. Withdrawal of NGF after completion of UPAR expression, however, prevents subsequent morphological differentiation (data not shown). These data suggest that the NGF-induced differentiation response requires, at some point, both a signal that can be delivered only by elevated UPAR present in cells and additional signals generated in a UPAR-independent manner from the NGF-TrkA interaction (Fig. 10). We conclude that UPAR is an immediate-early gene that is preferentially induced in PC12 cells by NGF and whose expression is necessary for subsequent progression of NGF-driven differentiation.

\section{Possible roles for UPAR induction in NGF-driven neuronal generation}

The plasminogen/plasminogen activator/UPAR system has been primarily associated with tissue remodeling in processes such as embryogenesis, tumor invasion, chemotaxis, tissue regeneration, and cellular adhesion (Ellis et al., 1991; Moller, 1993; Gyetko et al., 1994; Xing and Rabbani, 1996; Cantero et al., 1997; Bisgaard et al., 1998; Dear and Medcalf, 1998). Precedent also exists implicating the enhanced UPAR gene in neuronal differentiation. When murine dorsal root ganglia from early postnatal mice are dissociated and placed in culture, UPAR mRNA levels increase 163 -fold over a $20 \mathrm{hr}$ period (Hayden and Seeds, 1996). These authors suggest that modulation of UPAR levels in DRG neurons may "support a role for the PA system in facilitating axon extension and cell migration during development and regeneration of the PNS."

Although there is an inherent consistency in proposing that NGF-induced UPAR expression plays a role in the early cell and matrix remodeling that initiates axonal outgrowth of differentiating neurons, UPAR expression occurs at a very early stage of NGF-driven PC12 cell differentiation; UPAR is an immediateearly gene. Moreover, blockade of NGF-induced UPAR expression prevents secondary response gene induction occurring only 2 hr after NGF addition. Finally, in the "primed" PC12 cell differentiation system, in which NGF-differentiated cells are sheared and replated (Sano and Iwanaga, 1996; Wu and Bradshaw, 1996), UPAR antisera and antisense oligonucleotides have no effect on the rapid, protein synthesis-independent regeneration of neurites (data not shown). The data suggest that signaling to the cell nucleus from induced UPAR early in the NGF-induced differentiation response is required for continued expression of the differentiation program. Investigation of the nervous system of mice deficient in UPAR (Dewerchin et al., 1996) should help to clarify the role of UPAR in neuronal differentiation.

\section{UPAR forms signaling complexes in cells and can generate changes in gene transcription}

UPAR associates with src family tyrosine kinases (Resnati et al., 1996), $\beta 1, \beta 2$, and $\beta 3$ integrins (Wei et al., 1996, 1999), and PKC€ (Brodie et al., 1999) and activates diacylglycerol synthesis (Del Rosso et al., 1993; Anichini et al., 1997), cAMP formation (Goretzki and Mueller, 1997), inositol phosphate turnover (Vilhardt et al., 1999), release of calcium from intracellular stores (Cao et al., 1995), early response kinase-1 (ERK1) and ERK2 phosphorylation (Tang et al., 1998), STAT1 phosphorylation (Koshelnick et al., 1997), and immediate-early gene expression (Konakova et al., 1998). In human epithelial cells, UPAR coprecipitates with a serine/threonine kinase tentatively identified as $\mathrm{PKC} \epsilon$, along with two substrate cytokeratins (Busso et al., 1994). 


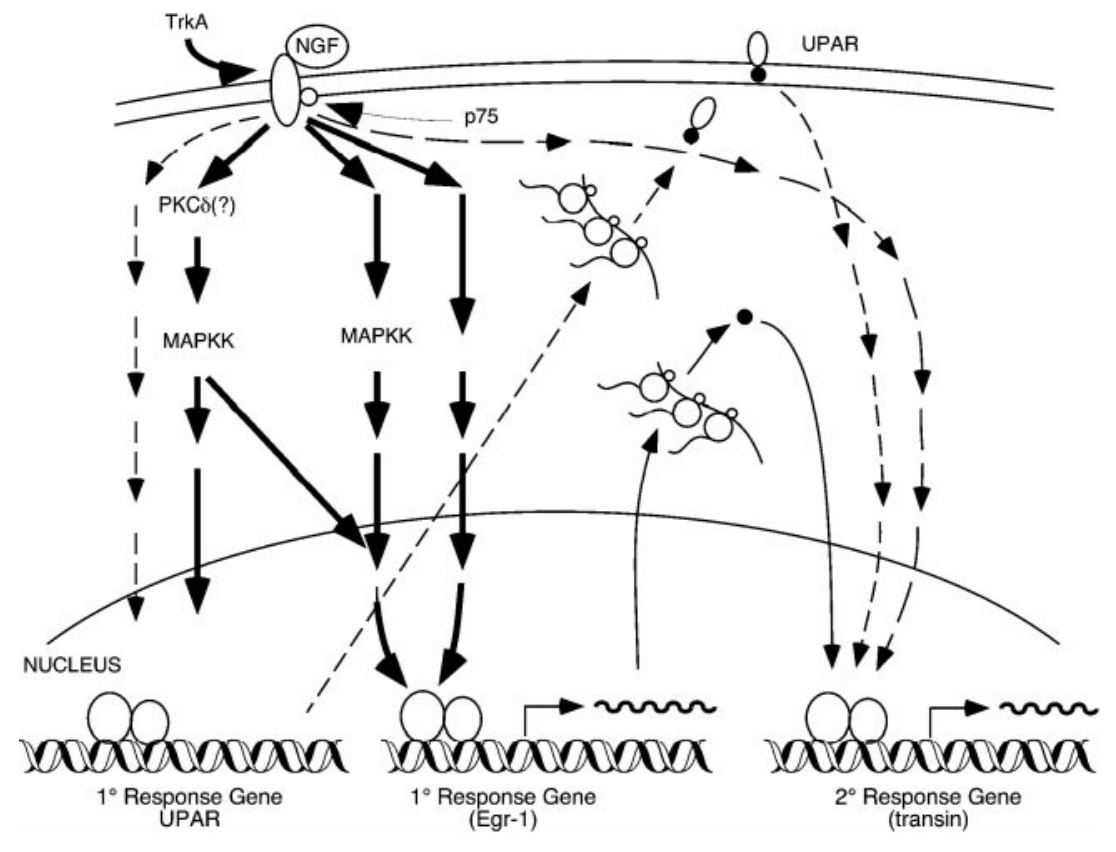

Figure 10. NGF-driven differentiation of PC12 cells requires a signal(s) generated from the UPAR immediateearly gene product. NGF binding to its receptor activates a signal transduction pathway(s) that preferentially induces UPAR expression (short broken and thick solid lines), as well as a pathway(s) — shared by EGF-that induces other immediate-early genes (thick solid line). Induced UPAR protein is incorporated into the cell membrane, where it generates a signal (short broken line), along with other primary response genes (thin solid line), that is required for the induction of secondary response genes such as collagenase- 1 and transin. Continued progress along the NGF-induced differentiation pathway requires both a signal(s) generated from the induced UPAR protein and additional signals that continue to be generated by the NGF-TrkA complex. As described in the text, PKC $\delta$ may modulate the NGF-restricted signal transduction pathway (Corbit et al., 1999), leading to the differential expression of UPAR observed in response to NGF versus EGF. MAPKK, MAP kinase kinase.
Because the cytokeratins are tissue specific, the data suggest that UPAR may form macromolecular signaling complexes that activate associated protein kinase $\mathrm{C}$ isoforms to phosphorylate target substrates in a tissue-specific manner.

It is of interest that activation of the MAPK and JAK/STAT pathways is required for the induction of collagenase and transin expression in astrocytes and fibroblasts in response to oncostatin M (Korzus et al., 1997). Like UPAR, the oncostatin M receptor is a GPI-linked molecule, with no cytoplasmic domain, that recruits the JAK/STAT-signaling components.

\section{UPAR activation should provide a means to analyze the molecular mechanisms by which NGF induces a differentiation response}

NGF and EGF stimulate similar, but not identical, signaling pathways and induce strongly overlapping, but not identical, sets of immediate-early genes. However, NGF treatment of PC12 cells blocks cell cycle progression and induces differentiation, whereas EGF stimulates proliferation and does not induce differentiation. What are the critical differences in NGF- and EGF-induced signals that result in these different responses? Identification of UPAR as a gene both preferentially induced by NGF and required for NGF-induced differentiation should facilitate the elucidation of specific aspects of NGF signaling required for differentiation.

Several laboratories reported that NGF treatment of PC12 cells leads to sustained activation of the MAP kinase pathway, whereas EGF treatment results in only transient MAP kinase activation (Cowley et al., 1994; Morooka and Nishida, 1998; Yaka et al., 1998; Brodie et al., 1999). Using constitutively activated and dominant-negative MAP kinase kinase mutants, Cowley et al. (1994) report that activation of MAP kinase kinase is necessary and sufficient for PC12 cell differentiation. However, it is not clear how the sustained activity of MAPKK in NGF-treated PC12 cells is converted into a differential gene expression program causal for neuronal differentiation.

One explanation for the difference in the response of PC12 cells to NGF and EGF postulates a role for sustained phosphorylation of CRE-binding protein (CREB) in response to NGF, as opposed to transient phosphorylation of CREB in response to EGF, and subsequent activation of secondary response genes. In this model, both NGF-induced immediate-early response genes and activated CREB are required for continuation of NGFmediated differentiation. Both components-the IEGs and activated CREB - are present in response to NGF, but not EGF, because of the sustained activation of CREB in response to NGF (Bonni et al., 1995; Finkbeiner et al., 1997; Deak et al., 1998). Although this model can account for differences in secondary response gene expression in response to NGF versus EGF, it does not explain the preferential induction by NGF of primary response genes such as PAI-1, VH6/MKP-3 (Vician et al., 1997), and UPAR.

Corbit et al. (1999) reported recently that ERK activation in PC12 cells is accomplished by distinct pathways in response to NGF and EGF; ERK activation by NGF is mediated by $\mathrm{PKC} \delta$, whereas ERK activation by EGF is $\mathrm{PKC} \delta$ independent. Moreover, antisense or pharmacological inhibition of $\mathrm{PKC} \delta$ activity blocked both NGF-induced ERK activation and morphological differentiation. Using both overexpression of an activated PKC $\epsilon$ isoform and expression of a dominant-negative form of PKC $\epsilon$, Brodie et al. (1999) implicated PKCe in NGF-induced PC12 differentiation. Unfortunately, neither study investigated the role of PKC $\delta$ or PKC $\epsilon$ in the NGF-induced expression of primary or secondary response genes. Consequently, it is not clear where in the NGF-induced differentiation pathway PKC $\delta$ and PKC $\epsilon$ activity is required. For example, PKC $\delta$-dependent differential activation of ERK could result in NGF-enhanced activation of UPAR expression. PKC $\epsilon$ activation by UPAR, after NGF induction, could be causal in the subsequent differentiation response (Fig. 10). Characterizing (1) the signal transduction pathways required for NGF-induced UPAR expression, (2) the components of the UPAR gene that confer NGF inducibility, (3) the signaling pathways from elevated UPAR in NGF-treated cells, and (4) the secondary response genes dependent on elevated UPAR expression should help to clarify the mechanism of neurotrophin-driven neuronal differentiation. 


\section{REFERENCES}

Agrawal S, Zhao Q (1998a) Antisense therapeutics. Curr Opin Chem Biol 2:519-528.

Agrawal S, Zhao Q (1998b) Mixed backbone oligonucleotides: improvement in oligonucleotide-induced toxicity in vivo. Antisense Nucleic Acid Drug Dev 8:135-139.

Altschul SF, Gish W, Miller W, Myers EW, Lipman DJ (1990) Basic local alignment search tool. J Mol Biol 215:403-410.

Anichini E, Zamperini A, Chevanne M, Caldini R, Pucci M, Fibbi G, Del Rosso M (1997) Interaction of urokinase-type plasminogen activator with its receptor rapidly induces activation of glucose transporters. Biochemistry 36:3076-3083.

Arenander AT, Lim RW, Varnum BC, Cole R, de Vellis J, Herschman HR (1989) TIS gene expression in cultured rat astrocytes: multiple pathways of induction by mitogens. J Neurosci Res 23:257-265.

Bisgaard HC, Santoni-Rugiu E, Nagy P, Thorgeirsson SS (1998) Modulation of the plasminogen activator/plasmin system in rat liver regenerating by recruitment of oval cells. Lab Invest 78:237-246.

Bonni A, Greenberg ME (1997) Neurotrophin regulation of gene expression. Can J Neurol Sci 24:272-283.

Bonni A, Ginty DD, Dudek H, Greenberg ME (1995) Serine 133phosphorylated CREB induces transcription via a cooperative mechanism that may confer specificity to neurotrophin signals. Mol Cell Neurosci 6:168-183.

Brodie C, Bogi K, Acs P, Lazarovici P, Petrovics G, Anderson WB, Blumberg PM (1999) Protein kinase C-epsilon plays a role in neurite outgrowth in response to epidermal growth factor and nerve growth factor in PC12 cells. Cell Growth Differ 10:183-191.

Brown AJ, Hutchings C, Burke JF, Mayne LV (1999) Application of a rapid method (targeted display) for the identification of differentially expressed mRNAs following NGF-induced neuronal differentiation in PC12 cells. Mol Cell Neurosci 13:119-130.

Busso N, Masur SK, Lazega D, Waxman S, Ossowski L (1994) Induction of cell migration by pro-urokinase binding to its receptor: possible mechanism for signal transduction in human epithelial cells. J Cell Biol $126: 259-270$

Cantero D, Friess H, Deflorin J, Zimmermann A, Brundler MA, Riesle E, Korc M, Buchler MW (1997) Enhanced expression of urokinase plasminogen activator and its receptor in pancreatic carcinoma. $\mathrm{Br} \mathrm{J}$ Cancer 75:388-395.

Cao D, Mizukami IF, Garni-Wagner BA, Kindzelskii AL, Todd III RF, Boxer LA, Petty HR (1995) Human urokinase-type plasminogen activator primes neutrophils for superoxide anion release. Possible roles of complement receptor type 3 and calcium. J Immunol 154:1817-1829.

Chao MV (1992) Neurotrophin receptors: a window into neuronal differentiation. Neuron 9:583-593.

Corbit KC, Foster DA, Rosner MRM (1999) Protein kinase Cdelta mediates neurogenic but not mitogenic activation of mitogen-activated protein kinase in neuronal cells. Mol Cell Biol 19:4209-4218.

Cowley S, Paterson H, Kemp P, Marshall CJ (1994) Activation of MAP kinase kinase is necessary and sufficient for $\mathrm{PC} 12$ differentiation and for transformation of NIH 3T3 cells. Cell 77:841-852.

Deak M, Clifton AD, Lucocq LM, Alessi DR (1998) Mitogen- and stress-activated protein kinase-1 (MSK1) is directly activated by MAPK and SAPK2/p38, and may mediate activation of CREB. EMBO J 17:4426-4441.

Dear AE, Medcalf RL (1998) The urokinase-type-plasminogenactivator receptor (CD87) is a pleiotropic molecule. Eur J Biochem 252:185-193.

DeFranco C, Damon DH, Endoh M, Wagner JA (1993) Nerve growth factor induces transcription of NGFIA through complex regulatory elements that are also sensitive to serum and phorbol 12-myristate 13-acetate. Mol Endocrinol 7:365-379.

Degryse B, Renati M, Rabbani SA, Villa A, Fazioli F, Blasi F (1999) Src-dependence and pertussis-toxin sensitivity of urokinase receptordependent chemotaxis and cytoskeleton reorganization in rat smooth muscle cells. Blood 94:649-662.

Del Rosso M, Anichini E, Pedersen N, Blasi F, Fibbi G, Pucci M, Ruggiero M (1993) Urokinase-urokinase receptor interaction: nonmitogenic signal transduction in human epidermal cells. Biochem Biophys Res Commun 190:347-352.

de Souza S, Lochner J, Machida CM, Matrisian LM, Ciment G (1995) A novel nerve growth factor-responsive element in the stromelysin-1 (transin) gene that is necessary and sufficient for gene expression in PC12 cells. J Biol Chem 270:9106-9114.
Dewerchin M, Nuffelen AV, Wallays G, Bouche A, Moons L, Carmeliet P, Mulligan RC, Collen D (1996) Generation and characterization of urokinase receptor-deficient mice. J Clin Invest 97:870-878.

Ellis V, Behrendt N, Dano K (1991) Plasminogen activation by receptorbound urokinase. A kinetic study with both cell-associated and isolated receptor. J Biol Chem 266:12752-12758.

Feldman JD, Vician L, Crispino M, Tocco G, Baudry M, Herschman HR (1998a) Seizure activity induces PIM-1 expression in brain. J Neurosci Res 53:502-509.

Feldman JD, Vician L, Crispino M, Tocco G, Marcheselli VL, Bazan NG, Baudry M, Herschman HR (1998b) KID-1, a protein kinase induced by depolarization in brain. J Biol Chem 273:16535-16543.

Finkbeiner S, Tavazoie SF, Maloratsky A, Jacobs KM, Harris KM, Greenberg ME (1997) CREB: a major mediator of neuronal neurotrophin responses. Neuron 19:1031-1047.

Goretzki L, Mueller BM (1997) Receptor-mediated endocytosis of urokinase-type plasminogen activator is regulated by cAMPdependent protein kinase. J Cell Sci 110:1395-1402.

Greene LA, Tischler AS (1976) Establishment of a noradrenergic clonal line of rat adrenal pheochromocytoma cells which respond to nerve growth factor. Proc Natl Acad Sci USA 73:2424-2428.

Gyetko MR, Todd III RF, Wilkinson CC, Sitrin RG (1994) The urokinase receptor is required for human monocyte chemotaxis in vitro. J Clin Invest 93:1380-1387.

Hayden SM, Seeds NW (1996) Modulated expression of plasminogen activator system components in cultured cells from dissociated mouse dorsal root ganglia. J Neurosci 16:2307-2317.

Herschman HR (1991) Primary response genes induced by growth factors and tumor promoters. Annu Rev Biochem 60:281-319.

Hilborn MD, Rane SG, Pollock JD (1997) EGF in combination with depolarization or cAMP produces morphological but not physiological differentiation in PC12 cells. J Neurosci Res 47:16-26.

Huff K, End D, Guroff G (1981) Nerve growth factor-induced alteration in the response of $\mathrm{PC} 12$ pheochromocytoma cells to epidermal growth factor. J Cell Biol 88:189-198.

Kaplan MD, Olschowka JA, O'Banion MK (1997) Cyclooxygenase-1 behaves as a delayed response gene in PC12 cells differentiated by nerve growth factor. J Biol Chem 272:18534-18537.

Konakova M, Hucho F, Schleuning WD (1998) Downstream targets of urokinase-type plasminogen-activator-mediated signal transduction. Eur J Biochem 253:421-429.

Korzus E, Nagase H, Rydell R, Travis J (1997) The mitogen-activated protein kinase and JAK-STAT signaling pathways are required for an oncostatin M-responsive element-mediated activation of matrix metalloproteinase 1 gene expression. J Biol Chem 272:1188-1196.

Koshelnick Y, Ehart M, Hufnagl P, Heinrich PC, Binder BR (1997) Urokinase receptor is associated with the components of the JAK1/ STAT1 signaling pathway and leads to activation of this pathway upon receptor clustering in the human kidney epithelial tumor cell line TCL-598. J Biol Chem 272:28563-28567.

Kujubu DA, Stimmel JB, Law RE, Herschman HR, Clarke S (1993) Early responses of PC-12 cells to NGF and EGF: effect of K252a and 5 '-methylthioadenosine on gene expression and membrane protein methylation. J Neurosci Res 36:58-65.

Lisitsyn N, Lisitsyn N, Wigler M (1993) Cloning the differences between two complex genomes. Science 259:946-951.

Machida CM, Rodland KD, Matrisian L, Magun BE, Ciment G (1989) NGF induction of the gene encoding the protease transin accompanies neuronal differentiation in PC12 cells. Neuron 2:1587-1596.

Moller LB (1993) Structure and function of the urokinase receptor. Blood Coagul Fibrinolysis 4:293-303.

Morooka T, Nishida E (1998) Requirement of p38 mitogen-activated protein kinase for neuronal differentiation in PC12 cells. J Biol Chem 273:24285-24288.

Peunova N, Enikolopov G (1995) Nitric oxide triggers a switch to growth arrest during differentiation of neuronal cells. Nature 375:68-73.

Ploug M, Ronne E, Behrendt N, Jensen AL, Blasi F, Dano K (1991) Cellular receptor for urokinase plasminogen activator. Carboxylterminal processing and membrane anchoring by glycosylphosphatidylinositol. J Biol Chem 266:1926-1933.

Poluha W, Schonhoff CM, Harrington KS, Lachyankar MB, Crosbie NE, Bulseco DA, Ross AH (1997) A novel, nerve growth factor-activated pathway involving nitric oxide, p53, and p21WAF1 regulates neuronal differentiation of PC12 cells. J Biol Chem 272:24002-24007. 
Possenti R, Eldridge JD, Paterson BM, Grasso A, Levi A (1989) A protein induced by NGF in PC12 cells is stored in secretory vesicles and released through the regulated pathway. EMBO J 8:2217-2223.

Rabbani SA (1998) Metalloproteases and urokinase in angiogenesis and tumor progression. In Vivo 12:135-142.

Rabbani SA, Rajwans N, Achbarou A, Murthy KK, Goltzman D (1994) Isolation and characterization of multiple isoforms of the rat urokinase receptor in osteoblasts. FEBS Lett 338:69-74.

Resnati M, Guttinger M, Valcamonica S, Sidenius N, Blasi F, Fazioli F (1996) Proteolytic cleavage of the urokinase receptor substitutes for the agonist-induced chemotactic effect. EMBO J 15:1572-1582.

Roldan AL, Cubellis MV, Masucci MT, Behrendt N, Lund LR, Dano K, Appella E, Blasi F (1990) Cloning and expression of the receptor for human urokinase plasminogen activator, a central molecule in cell surface, plasmin dependent proteolysis. EMBO J 9:467-474.

Sano M, Iwanaga M (1996) Re-examination of the local control by nerve growth factor of the outgrowth of neurites in PC12D cells. Brain Res 730:212-222.

Sitrin RG, Todd III RF, Albrecht E, Gyetko MR (1996) The urokinase receptor (CD87) facilitates CD11b/CD18-mediated adhesion of human monocytes. J Clin Invest 97:1942-1951.

Tang H, Kerins DM, Hao Q, Inagami T, Vaughan DE (1998) The urokinase-type plasminogen activator receptor mediates tyrosine phosphorylation of focal adhesion proteins and activation of mitogenactivated protein kinase in cultured endothelial cells. J Biol Chem 273:18268-18272.

Toledo-Aral JJ, Brehm P, Halegoua S, Mandel G (1995) A single pulse of nerve growth factor triggers long-term neuronal excitability through sodium channel gene induction. Neuron 14:607-611.

Vician L, Basconcillo R, Herschman HR (1997) Identification of genes preferentially induced by nerve growth factor versus epidermal growth factor in PC12 pheochromocytoma cells by means of representational difference analysis. J Neurosci Res 50:32-43.

Vilhardt F, Nielsen M, Sandvig K, van Deurs B (1999) Urokinase-type plasminogen activator receptor is internalized by different mechanisms in polarized and nonpolarized Madin-Darby canine kidney epithelial cells. Mol Biol Cell 10:179-195.

Wang Y, Dang J, Johnson LK, Selhamer JJ, Doe WF (1995) Structure of the human urokinase receptor gene and its similarity to CD59 and the Ly-6 family. Eur J Biochem 227:116-122.

Wei Y, Lukashev M, Simon DI, Bodary SC, Rosenberg S, Doyle MV, Chapman HA (1996) Regulation of integrin function by the urokinase receptor. Science 273:1551-1555.

Wei Y, Yang X, Liu Q, Wilkins JA, Chapman HA (1999) A role for caveolin and the urokinase receptor in integrin-mediated adhesion and signaling. J Cell Biol 144:1285-1294.

Wu YY, Bradshaw RA (1996) Induction of neurite outgrowth by interleukin-6 is accompanied by activation of Stat 3 signaling pathway in a variant PC12 cell (E2) line. J Biol Chem 271:13023-13032.

Xing RH, Rabbani SA (1996) Overexpression of urokinase receptor in breast cancer cells results in increased tumor invasion, growth and metastasis. Int J Cancer 67:423-429.

Yaka R, Gamliel A, Gurwitz D, Stein R (1998) NGF induces transient but not sustained activation of ERK in PC12 mutant cells incapable of differentiating. J Cell Biochem 70:425-432. 